\title{
Sustainablity of Madarasa Teachers: A Case Study of Belgaum District
}

\author{
${ }^{1}$ Dr. Z. A. Pathan, ${ }^{2}$ Md. M. A. Mujawar \\ ${ }^{1}$ H.O.D., Department of Sociology, Al-Ameen College, Belgaum, Karnataka \\ ${ }^{2}$ Research Scholar for Ph.D, Department of Social Work, CMJ University Meghalaya, Shillong
}

\section{Introduction:}

Education for Sustainable Development allows every human being to acquire the knowledge, skills, attitudes and values necessary to shape a sustainable future.

Education for Sustainable Development means including key sustainable development issues into teaching and learning; for example, climate change, disaster risk reduction, biodiversity, poverty reduction, and sustainable consumption. It also requires participatory teaching and learning methods that motivate and empower learners to change their behaviour and take action for sustainable development. Education for Sustainable Development consequently promotes competencies like critical thinking, imagining future scenarios and making decisions in a collaborative way.

\section{Concept of Madrasa:}

The word Madrasa is derived from the triconsonantal root (d-r-s), which relates to learning or teaching, through the wazn (form/stem) therefore, Madrasa literally means "a place where learning/teaching is done".

In the Arabic language, the word (Madrasa) simply means the same as school does in the English language, whether that is private, public or parochial school, as well as for any primary or secondary school whether Muslim, non-Muslim, or secular. Unlike the understanding of the word school in British English, the word Madrasa is like the term school in American English, in that it can refer to a university-level or postgraduate school as well. For example, in the Ottoman Empire during the Early Modern Period, Madrasa had lower schools and specialized schools where the students became known as danismends. The correct Arabic word for a university, however, is The Hebrew cognate midrasha also connotes the meaning of a place of learning.

\section{Constitutional Privileges To Muslim Institutions:}

Regarding the freedom of adhering to different religious beliefs our Constitution says "Subject to public order, morality and health and to other provisions of this part, all persons are equally entitled to freedom of conscience and the right to freely profess, practice and propagate religion." [Article 25 (1)]

In the context of rights of minorities on the question of establishing and managing educational institutions, it is said "All minorities, whether based on religion or language, shall have the right to establish and administer educational institutions of their choice." [Article 30 (1)]

A direction to all governments is given in this regard "The state shall not, in granting aid to educational institutions, discriminate against any educational institution on the ground that it is under the management of a minority, whether based on religion or language." [Article 30 (2)]

\section{Madrasa Education: Past \& Present:}

The Muslim population numbers more than a hundred crore across the world. It is too difficult to specifically assess the number of Madrasa spread over different countries. India ranks third, after Indonesia and Pakistan in terms of Muslim population. Here also there is a long tradition of Madrasa education.

Institutes like Madrasa emerged as a historical necessity. The intention was expressed quite explicitly in 1780, when the Alia Madrasa College, Calcutta was established "to promote the study of the Arabic and Persian languages and Mohammedan law, with a view more especially to the production of qualified officers for the court of justice." People capable of reading and explaining the book of law written in Farsi was an urgent need and Warren Hastings, responded to the demand of a section of Muslims to establish a Madrasa college. A Sanskrit college also received British patronage for similar reasons. So it is a fact that studies in both Hindu and Muslim theology received British favor. For the two successive centuries of the Imperial age there was no exception to the above mentioned fact. 


\section{Statement of the Problem:}

The rise in level of education leads to better employment opportunities and as far as religious education is concerned Madrasas play an important role not only in imparting education but also it gives employment to the madarasa teachers, where the teachers are paid for their services. The salary paid to the teacher in Madarasa is not as lucrative as compared to teacher in other fields but it cannot be declared that the income of the teachers in madarasas is not enough to sustain their living. Thus an urgent necessity was felt to analyse the economic conditions of the teachers imparting education in madarasas and to answer whether they have sustainable earnings or not?

\section{Review Of Literature:}

Muhammadullah Khalil Qasmi, Manak, (2005) "Madrasa Education: Its Strength and Weakness", Muhammadullah khalili have made an efforts to study the Historical background of Madrasa, Freedom Movement (1857) and Madrasa, Education systems through ages, Existing system of Madrasa education, Changes recommended in Madrasa system, Division between worldly and Islamic education the modern syllabus system and problems, Modernization of Madrasa, Misconception regarding Madrasa and Roles of Madrasa in various aspects of life.

Muhammad Sajid Qasmi (2005) in "Madrasa Education Frameworks"the author have analysed aspects in relation to Madrasa education i.e., it's Historical background of the madarasas and the protagonists of this education system (Dars-e-Nizami) and the subjects taught at Arabic Madrasa serve the requirements of the students were studied.

Ziya A Pathan (2006) in his thesis entitled "Muslim Elite: A Sociological analysis" have analysed and exhibits that education plays a great role in the emergence of Muslim elite. As the research was carried in Belgaum district and various educational institutions were extensively studied and importance of Muslim education was highlighted.

Yoginder Sikand (2008), "Madrasa Reforms: Indian Muslim Voices", has expressed that Madrasa have kept the candle of divine knowledge (Ilm) burning even in adverse times. Though the Madrasa has played a pivotal role in providing leadership and scholars to the Muslim Society especially in the South Asia, but the fact must also be acknowledged that in due course of time there has been degradation to the role of Madrasa in Society.

\section{Locale of the Study:}

The study area is located in the northwestern part of the Karnataka State and falls within the northern maidan region. The Belgaum district (named after its Head Quarters - Belgaum) extends between $\mathbf{1 5 . 2 3}^{\mathbf{0}}$ and $\mathbf{1 6 . 5 8}^{\mathbf{0}}$ north latitude and $\mathbf{7 5 . 5}^{\mathbf{0}}$ and $\mathbf{7 5 . 8}^{\mathbf{0}}$ east longitude. Dharwad and Uttar Kannada districts bound the district in the north by Sangli and Kolhapur districts and on the west by parts of Kolhapur and Ratnagiri of Maharashtra State and Goa on the east by Bijapur district in the South.

\section{Objectives of Study:}

The main objective for the present study is to know the economic conditions of Madarasa teachers and to analyse the educational attainment of the respondents

\section{Research Methodology:}

In this study, efforts are made to understand the life cycle of the concerned unit under study, the interaction between factors that explain the present status or the development over a period of time. With the help of the case study method attempts are made to get an intuition into the extreme case whose unique features are not reflected by the usual statistical methods and examined the complex factors involved in a given situation so as to identify the causal factors acting on it.

\section{Selection of Respondents:}

After resolving the nature and the respondents for this research work, information is compiled through well-processed questionnaires by contacting the various government offices. The current study includes the male teacher imparting education in Madarasas of Belgaum District are preferred for the collection of primary data. The respondents are selected through the random sampling technique. 


\section{Source of Data:}

This study is based on both primary and secondary data. Primary data is collected with the help of the pre-ordained closed-ended questionnaire, circulated \& canvassed to the respondents. The Secondary data is collected from records of Muslim institutions, personal contacts, through friends, reports, published articles, thesis in the book form and other published literature pertaining to research subject.

\section{Scope \& limitation:}

The following are the limitations of the Study:

1. The Study is confined to the Madarasas only.

2. The Study covers Madarasas in Belgaum District of Karnataka State.

3. The Study is mainly based on Primary data collected from the respondents of Belgaum Districts.

\section{Sustainablity Of Teachers Imparting Education In Madarasa}

Table 1

Age-Composition of Respondents

\begin{tabular}{|c|l|c|c|}
\hline Sl.No & $\begin{array}{l}\text { Age Categories } \\
\text { (In Years) }\end{array}$ & Respondents & Percentage \\
\hline 1 & Less than 30 & 05 & $\mathbf{0 5}$ \\
\hline 2 & $\mathbf{3 0}$ to 35 & 15 & $\mathbf{5 0 . 0 0}$ \\
\hline 3 & $\mathbf{3 6}$ to 40 & $\mathbf{0 2}$ & $\mathbf{0 6 . 6 7}$ \\
\hline 4 & 41 to 45 & 06 & $\mathbf{0 6 . 0 0}$ \\
\hline 5 & Above 45 & $\mathbf{0 2}$ & $\mathbf{0 6 . 6 7}$ \\
\hline & Total & $\mathbf{3 0}$ & $\mathbf{1 0 0 . 0 0}$ \\
\hline
\end{tabular}

Source : Field Survey

Table. No. 1 reveals the age composition of the respondents. It reveals that 16.66 percent of the respondents are in the age group of less than 30 year, 50.00 percent are in age group of $30-35$ year \& 06.67 percent falls in the age group of 36-40 year and the representation of above 41-45 year is only 20.00 percent and above 4 year is only 06.67 percent.

The table reveals that majority of the respondents are either in the age group of less than 30 or 30-35 years, this is due to, lot of importance given to youngster to educate \& impart religious education.

Table No. 2

Martial Status-Composition on of Respondents

\begin{tabular}{|c|l|c|c|}
\hline Sl.No & Martial Status & Respondents & Percentage \\
\hline 1 & Unmarried & $\mathbf{0 0}$ & $\mathbf{0 0 0 . 0 0}$ \\
\hline 2 & Married & $\mathbf{3 0}$ & $\mathbf{1 0 0 . 0 0}$ \\
\hline & Total & $\mathbf{3 0}$ & $\mathbf{1 0 0 . 0 0}$ \\
\hline
\end{tabular}

Source: Field Survey

Table No. 2 derives the marital status of the respondents. It derives that 00.00 percent of the respondents are unmarried and 100.00 percent are married.

The table derives that majority of the respondents are married because management is to maintained by those person who are financially and mentally stable and are capable of raising the funds.

Table No. 3

Educational attainment of the Respondents

\begin{tabular}{|c|l|c|c|}
\hline Sl.No & Self & Respondents & Percentage \\
\hline $\mathbf{1}$ & Illiterate & $\mathbf{0 0}$ & $\mathbf{0 0 . 0 0}$ \\
\hline $\mathbf{2}$ & Primary & $\mathbf{2 4}$ & $\mathbf{8 0 . 0 0}$ \\
\hline $\mathbf{3}$ & Secondary & $\mathbf{0 3}$ & $\mathbf{1 0 . 0 0}$ \\
\hline $\mathbf{4}$ & S.S.L.C & $\mathbf{0 3}$ & $\mathbf{1 0 . 0 0}$ \\
\hline $\mathbf{5}$ & Graduate & $\mathbf{0 0}$ & $\mathbf{0 0 . 0 0}$ \\
\hline $\mathbf{6}$ & Post Graduate & $\mathbf{0 0}$ & $\mathbf{0 0 . 0 0}$ \\
\hline & Total & $\mathbf{3 0}$ & $\mathbf{1 0 0 . 0 0}$ \\
\hline
\end{tabular}

Source: Field Survey 
Table No. 3 shows the educational attainment of the respondents. It shows that 00.00 percent of the respondents are illiterate, 80.00 percent of the respondents are primary qualified \& 10.00 percent of the respondents are secondary qualified and the representation of above S.S.L.C is 10.00 percent and graduate are only 00.00 percent.

The table shows that majority of the respondents are primarily educated it is due to lot of importance given to religious education in respondent's family.

Table No. 4

Income Per Month of Respondents

\begin{tabular}{|c|c|c|c|}
\hline Sl.No & Income per Month & Respondents & Percentage \\
\hline 1 & Less than 2500/- & 00 & 00.00 \\
\hline 2 & $2501 /-$ to $5000 /-$ & 13 & 43.33 \\
\hline 3 & $5001 /-$ to $7500 /-$ & 16 & 53.33 \\
\hline 4 & $7501 /-$ to $10000 /-$ & 00 & 00.00 \\
\hline \multirow[t]{2}{*}{5} & Above 10001/- & 01 & 03.33 \\
\hline & Total & 30 & 100.00 \\
\hline
\end{tabular}

Source: Field Survey

Table No. 4 shows the income per month of the respondents. It shows that 00.00 percent have less than 2500/- , 43.33 percent earn 2501/- to 5000/- \& 53.33 percent earn 5001/- to 7500/- and the representation of above $7501 /$ - to $10000 /$ - is 00.00 percent and above $10001 /$ - is only 03.33 percent.

The table shows that majority of the respondents earn 5001/- to 7500/- per month and on the basis of discussion with the respondents it was revealed that they also have other source of earning by giving tutions and summer camps etc.

Table No. 5

Occupational Background of Respondent's Father

\begin{tabular}{|c|l|c|c|}
\hline Sl.No & Father & Respondents & Percentage \\
\hline $\mathbf{1}$ & Agriculture & $\mathbf{0 0}$ & $\mathbf{0 0 . 0 0}$ \\
\hline $\mathbf{2}$ & Business & $\mathbf{2 2}$ & $\mathbf{7 3 . 3 3}$ \\
\hline $\mathbf{3}$ & Administrative & $\mathbf{0 0}$ & $\mathbf{0 0 . 0 0}$ \\
\hline $\mathbf{4}$ & Professional & $\mathbf{0 0}$ & $\mathbf{0 0 . 0 0}$ \\
\hline $\mathbf{5}$ & Social Service & $\mathbf{0 0}$ & $\mathbf{0 0 . 0 0}$ \\
\hline $\mathbf{6}$ & Alim & $\mathbf{0 8}$ & $\mathbf{2 6 . 6 7}$ \\
\hline & Total & $\mathbf{3 0}$ & $\mathbf{1 0 0 . 0 0}$ \\
\hline
\end{tabular}

Source: Field Survey

Table No. 5 shows the occupational background of the respondents father. It shows that 00.00 percent are of agriculture background ,73.33 percent are of business background \& 00.00 percent are of administrative background and the representation of above professional background is 00.00 percent, service background are of 00.00 percent and alim (priest) background are only 26.67 percent.

The table shows that occupational background of the respondents' father is business the main cause of this is many of them like to take business as their livelihood this is due to less education or religious sanctity to business.

Table No. 6

Nature of House of Respondents

\begin{tabular}{|c|l|c|c|}
\hline Sl.No & House & Respondents & Percentage \\
\hline 1 & Rented & 05 & 16.67 \\
\hline 2 & Owned & 25 & 83.33 \\
\hline 3 & On Lease & 00 & 00.00 \\
\hline & Total & 30 & 100.00 \\
\hline
\end{tabular}

Source: Field Survey 
Table No. 6 shows the type of houses of the respondents. It shows that 16.67 percent of the respondents live in rented house, 83.33 percent live in owned house \& none in leased house. The table shows that majority of the respondents live in owned house.

Table No. 7

Land ownership of the Respondents

\begin{tabular}{|c|l|c|c|}
\hline Sl.No & Land & Respondents & Percentage \\
\hline 1 & Yes & $\mathbf{1 0}$ & $\mathbf{3 3 . 3 3}$ \\
\hline 2 & No & $\mathbf{2 0}$ & $\mathbf{6 6 . 6 7}$ \\
\hline & Total & $\mathbf{3 0}$ & $\mathbf{1 0 0 . 0 0}$ \\
\hline
\end{tabular}

Source: Field Survey

Table No.7 derives the land owned by the respondents'. It derives that 33.33 percent of the respondents own land and only 66.67 percent don't own land. The table exhibits that majority of the respondents don't own land because many of them do not have sound economic background.

Table No. 8

Immovable Property of the Respondents

\begin{tabular}{|c|c|c|c|}
\hline Sl.No & Immovable Property & Respondents & Percentage \\
\hline 1 & Yes & 13 & 43.33 \\
\hline 2 & No & 17 & 56.67 \\
\hline & Total & 30 & 100.00 \\
\hline
\end{tabular}

Source: Field Survey

Table No.8 shows the immovable property owned by the respondent's. It shows that 43.33 percent of the respondents own immovable property and 56.67 percent don't own immovable property.

The table shows that majority of the respondents don't own immovable property because many are from poor families.

Table No. 9

Property ownership of the Respondents $\quad \mathrm{N}=13$

\begin{tabular}{|c|l|c|c|}
\hline Sl.No & Type of Property & Respondents & Percentage \\
\hline 1 & Open Site & 10 & 76.92 \\
\hline 2 & House's & 03 & 23.08 \\
\hline 3 & Shop's & 00 & 00.00 \\
\hline & Total & 13 & 100.00 \\
\hline
\end{tabular}

Source: Field Survey

Table No. 9 reveals the type of property owned by the respondents'. It reveals that 76.92 percent of the respondents own open site, 23.08 percent own house's and none have ownership of shop.

The table shows type of property owned by the respondents' and it reflects majority of them have open sites which is mostly uncultivated land or grazing land.

\section{Findings And Conclusion:}

Before the advent of Islam education was considered to be the monopoly of Brahmins. They excluded the lower class people to acquire knowledge because they thought themselves to be superior. There were mass revolts against this notion resulting in the shape of Buddhism and Jainism, but soon these religions grew weaker and the previous conditions returned. Although none can deny the glory of Nalanda and Taxila universities of India, the fact cannot be over looked that the common people were always deprived of education in early Hindu periods. When Islam came to India it had to fight this mindset that prevailed in the masses. Ultimately, due to the efforts of Muslim rulers every citizen of the country, whether Muslim or Hindu, man or woman, rich or poor, was enshrined with the right to acquire knowledge. Some of the major findings of the present study are:

- The table shows that majority of the respondents are male because we have surveyed only five madarasa which are only for male students and teaching staff is completely imparting education to male students of Muslim community. 
- The table reveals that majority of the respondents are either in the age group of less than 30 or 30-35 years, this is due to, lot of importance is given to youngster to give education in madarasa.

- The table derives that majority of the respondents are married and it shows that they are able to maintain their family on their existing income; it reflects sustanaibility and self sufficiency of the respondents.

- The table shows that majority of the respondents earn more than 2501/- to 5000/- or 5001/- to 7500/- per month, they also have alternate source of income like through tuitions and summer camps etc.

- The table shows that majority of the respondents traditional occupational background is business, the main cause is that lot of Muslim family owe themselves to business activities.

- The table shows that majority of the respondents live in owned house.

- The table reveals type of property owned by the majority is open site's' which is mostly barren land mostly used for grazing cattles.

\section{Bibliography}

[1] Arjomand, Said Amir, 'The Law, Agency, and Policy in Medieval Islamic Society: Development of the Institutions of Learning from the Tenth to the Fifteenth Century', Comparative Studies in Society and History, 1999

[2] Berkey, Jonathan, The Transmission of Knowledge in Medieval Cairo: A Social History of Islamic Education, Princeton University Press, 1992

[3] Ephrat, Daphna, A learned society in a period of transition: the Sunni ulama of eleventh century Baghdad, Albany: State University of New York, Press, 2000

[4] Gilbert, Joan E., 'Institutionalization of Muslim Scholarship and Professionalization of the Ulama in Medieval Damascus', Studia Islamica 52, 1980.

[5] Leiser, Gary, 'Notes on the Madrasa in medieval Islamic society', Muslim World, 1986

[6] Lowry, Joseph E et al. (eds.), Law and Education in Medieval Islam: Studies in Memory of George Makdisi, E.J.W. Gibb Memorial Trust, 2004.

[7] Mahamid, Hatim, 'The Construction of Islamic-Educational Institutions in Mamluk Gaza', Nebula 2007

[8] Mortel, RT, 'Madrasa in Mecca during the Medieval Period: A Descriptive Study Based on Literary Sources', Bulletin of SOAS, 1997.

[9] Muhammad Sajid Qasmi, "Madrasa Education Frameworks, Manak Publications, New Delhi, 2005

[10] Muhammadullah Khali Qasmi, "Madrasa Education: Its Strength and Weakness", New Delhi: Manas Publications, 2005

[11] Yoginder Sikand, "Madrasa Reforms: Indian Muslim Voices", Vikas Adhyayan Kendra (VAK),Mumbai, 2008

[12] Z. A. Pathan, "Muslim Elite: A Sociological Analysis", serials publications, New Delhi, 2008 